\title{
Vegetation Database of Guaramacal, Andes, Venezuela
}

\author{
Nidia Cuello
}

\begin{abstract}
The Vegetation Database of Guaramacal, Andes, Venezuela (GIVD ID SA-VE-001) includes a set of relevés gathered from montane rainforest vegetation. Ramal de Guaramacal is a mountain range extending approximately 30 kilometres northeast towards the eastern end of the Venezuelan Andes; between $9^{\circ} 05^{\prime} 21^{\prime \prime} \mathrm{N}$ and $70^{\circ} 00^{\prime} 20^{\prime \prime} \mathrm{W}$. The data were collected within the framework of a project aiming to study the floristic and vegetation diversity of the Guaramacal National Park. The forest data contains a total of 44 samples, collected by the author from 1995 to 2006. They are located at different altitudes between 1,300 and 3,000 m, distributed throughout the different Park sectors. The data were used to characterize the montane rainforest vegetation of Ramal de Guaramacal and to establish a syntaxonomic scheme which represents the first attempt to classify the vegetation phytosociologically based on a quantitative data set from an entire mountain range in the Venezuelan Andes. An analysis of forest functional diversity changes with altitude has also been performed based on the forest database.
\end{abstract}

Keywords: forest; montane rainforest; national park.

GIVD Database ID: SA-VE-001

Last update: 2012-07-06

Vegetation Database Guaramacal, Andes, Venezuela

Scope: Structure and floristic composition of montane forests (LMRF, UMRF and SARF) of Ramal de Guaramacal in the Andes of Venezuela.

Status: emerging

Period: 1995-2006

Database manager(s): Nidia Cuello (ncuello@cantv.net)

Owner: Nidia L. Cuello A. (private)

Web address: [NA]

Availability: according to a specific agreement

Database format(s): Excel

Publication: Phytocoenologia 39(1):109-156

Plot type(s): normal plots

Non-overlapping plots: 44

Total plot observations: 44

Online upload: [NA]

Online search: [NA]

Countries: VE: $100.0 \%$

Forest: $100 \%$ - Non-forest: aquatic: $0 \%$; semi-aquatic: $0 \%$; arctic-alpine: $0 \%$; natural: $0 \%$; semi-natural: $0 \%$; anthropogenic: $0 \%$

Guilds: only trees and shrubs: $100 \%$

Environmental data: altitude: $100 \%$; slope inclination: $100 \%$; soil pH: $15 \%$; other soil attributes: $100 \%$; land use categories: $15 \%$

Performance measure(s): number of individuals: $100 \%$; measurements like diameter or height of trees: $100 \%$

Geographic localisation: GPS coordinates (precision $25 \mathrm{~m}$ or less): $100 \%$

Sampling periods: $1990-1999: 30.0 \%$; $2000-2009: 70.0 \%$

Information as of 2012-07-12; further details and future updates available from http://www.givd.info/ID/SA-VE-001

Nidia Cuello (ncuello@cantv.net)

Herbario Universitario (PORT)-BioCentro, Universidad Nacional Experimental de los Llanos Occidentales "Ezequiel Zamora",

Carretera via Biscucuy, 3323 Guanare, VENEZUELA 